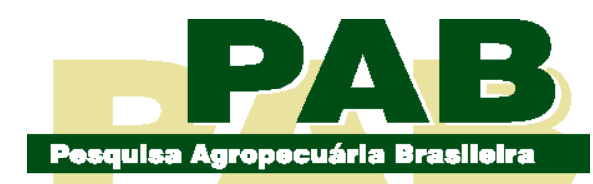

ISSN 1678-3921

Journal homepage: www.embrapa.br/pab

For manuscript submission and journal contents, access: www.scielo.br/pab
Maday Priscila Piva Deon(1) (D),

Álvaro José de Almeida Bicudo ${ }^{(2)}$ (iD) and Ricardo Yuji Sado(1®) (iD)

(1) Universidade Tecnológica Federal do Paraná, Campus Dois Vizinhos, Estrada para Boa Esperança, Km 04, Comunidade São Cristóvão, CEP 85660-000 Dois Vizinhos, PR, Brazil. E-mail: maday_priscila@hotmail.com, ricardoysado@utfpr.edu.br

(2) Universidade Federal do Paraná, Setor Palotina, Rua Pioneiro, № 2.153, CEP 85950-000 Palotina, PR, Brazil. E-mail: ajabicudo@gmail.com

$\bowtie$ Corresponding author

Received

February 25, 2021

Accepted

September 22, 2021

How to cite

DEON, M.P.P.; BICUDO, Á.J. de A.; SADO,

R.Y. Performance, hematology, and immunology of pacu in response to dietary supplementation with fructooligosaccharides. Pesquisa Agropecuária Brasileira, v.56, e02460, 2021 DOI: https://doi.org/10.1590/S1678-3921. pab2021.v56.02460.

\section{Performance, hematology, and immunology of pacu in response to dietary supplementation with fructooligosaccharides}

\begin{abstract}
The objective of this work was to evaluate the effects of dietary supplementation with fructooligosaccharides (FOS) on the performance, hematology, and immunology of pacu (Piaractus mesopotamicus) juveniles. A total of 0 (control), 2.0 , and $4.0 \mathrm{~g} \mathrm{~kg}^{-1}$ of the probiotic were added to the fish diets. Fish $(49.3 \pm 4.3 \mathrm{~g})$ were allotted into 12 tanks of $60 \mathrm{~L}$, in a completely randomized design $(n=4)$. After 60 days, final weight, weight gain, specific growth rate, and feed conversion ratio were improved in the fish fed with the prebiotic, although feed intake was not affected by the treatments. The number of red blood cells was higher only in fish fed with $2.0 \mathrm{~g} \mathrm{~kg}^{-1} \mathrm{FOS}$. The opposite was observed for the hematimetric indices mean corpuscular volume and mean corpuscular hemoglobin, which decreased in fish fed with $2.0 \mathrm{~g}$ $\mathrm{kg}^{-1} \mathrm{FOS}$. The number of defense cells, such as leukocytes and thrombocytes, also increased in the prebiotic treatments. The evaluated immunological parameters were not influenced by prebiotic supplementation. Dietary FOS supplementation improved pacu growth and health.
\end{abstract}

Index terms: Piaractus mesopotamicus, feed additives, fish nutrition, prebiotics.

\section{Desempenho, hematologia e imunologia do pacu em resposta à suplementação dietética com frutooligossacarídeos}

Resumo - O objetivo deste trabalho foi avaliar o efeito da suplementação dietética com frutooligossacarídeos (FOS) sobre o desempenho, a hematologia e o sistema imune de juvenis de pacu (Piaractus mesopotamicus). Um total de 0 (controle), 2,0 e 4,0 $\mathrm{g} \mathrm{kg}^{-1}$ do prebiótico foi adicionado à dieta dos peixes. Os peixes $(49,3 \pm 4,3 \mathrm{~g})$ foram alocados em 12 tanques de $60 \mathrm{~L}$, em delineamento inteiramente casualizado $(n=4)$. Após 60 dias, o peso final, o ganho de peso, a taxa de crescimento específico e a conversão alimentar melhorou nos peixes alimentados com o prebiótico, apesar do consumo de ração não ter sido afetado pelos tratamentos. O número de células vermelhas foi maior apenas nos peixes alimentados com $2,0 \mathrm{~g} \mathrm{~kg}^{-1}$ de FOS. O oposto foi observado para os índices hematimétricos de volume corpuscular médio e hemoglobina corpuscular média, os quais diminuíram nos peixes alimentados com $2,0 \mathrm{~g} \mathrm{~kg}^{-1}$ de FOS. O número de células de defesa, como leucócitos e trombócitos, também aumentou nos tratamentos com o prebiótico. Os parâmetros imunológicos avaliados não foram afetados pela suplementação do prebiótico. A suplementação dietética com FOS melhorou o crescimento e a saúde do pacu.

Termos para indexação: Piaractus mesopotamicus, aditivos alimentares, nutrição de peixes, prebióticos. 


\section{Introduction}

Prebiotics are indigestible substances that promote beneficial effects on the growth, feed efficiency, and immune response of the host (Guerreiro et al., 2018a). Fructooligosaccharides (FOS) are a common type of prebiotic derived from plants, consisting of a nondigestible linear chain of fructose units (Guerreiro et al., 2018b). Their effects on aquatic organisms began to be studied in Atlantic salmon [Salmo salar (Linnaeus, 1758)] farms, aiming to reduce antibiotic use (Grisdale-Helland et al., 2008). In the past decade, the study of FOS in aquaculture has grown substantially, registering positive effects on the growth and immunological parameters of several fish species such as sturgeon [Acipenser stellatus (Pallas, 1771)] (Akrami et al., 2013), rainbow trout [Oncorhynchus mykiss (Walbaum, 1792)] (Ortiz et al., 2013; Cid García et al., 2019), blunt snout bream [Megalobrama amblycephala (Yih, 1955)] (Zhang etal.,2014), Japanese sea bass [Lateolabrax japonicus (Cuvier, 1828)] (Wang \& Li, 2020), and hybrid catfish [Pangasianodon gigas (Chevey, 1931) x Pangasianodon hypophthalmus (Sauvage, 1878)] (Hahor et al., 2019).

Pacu [Piaractus mesopotamicus (Holmberg, 1887)] is an omnivorous freshwater fish of the Serrasalmidae family important for aquaculture in South American countries, including Brazil (Valladão et al., 2018). Piaractus species, such as $P$. mesopotamicus and Piaractus brachypomus (Cuvier, 1818), as well as their respective hybrids with tambaqui [Colossoma macropomum (Cuvier, 1816)], i.e., tambacu and tambatinga, represented $9.8 \%$ of the Brazilian production of cultivated fish in 2019 (IBGE, 2020). Despite the economic importance to South American aquaculture, the knowledge about the effects of prebiotics in Piaractus species is still limited to previous studies in which the diets of pacu were supplemented with $\beta$-glucans (Biller-Takahashi et al., 2014) and mannanoligosaccharides (Sado et al., 2014a, 2014b). Besides Serrasalmidae species, the effect of dietary supplementation with FOS has only been evaluated in tambaqui (Paz et al., 2019), with the inclusion of 1.0 to $5.0 \mathrm{~g} \mathrm{~kg}^{-1}$ of the prebiotic being recommended.

Although the positive effects of prebiotics on the performance of terrestrial and aquatic animals have been reported (Nawaz et al., 2018), contrary results were also obtained, with no benefits to fish due to diet supplementation with prebiotics (Liu et al., 2017). Especially regarding aquatic organisms, the inconsistent results of prebiotics can be related to prebiotic type and source, dietary inclusion levels, environmental conditions (ectothermy), stage development, and interspecific physiological features (Guerreiro et al., 2018a).

The objective of this work was to evaluate the effects of dietary supplementation with fructooligosaccharides on the performance, hematology, and immunology of pacu juveniles.

\section{Materials and Methods}

All experimental procedures were approved by the ethics committee on animal use of Universidade Tecnológica Federal do Paraná (protocol number 2017-021). Juvenile pacu were obtained from the Piscicultura Daniela commercial farm (Francisco Beltrão, PR, Brazil). Fish were fed with the same extruded commercial mix powder, with minimum guarantee levels of $320 \mathrm{~g} \mathrm{~kg}^{-1}$ crude protein and 50 $\mathrm{g} \mathrm{kg}^{-1}$ crude lipid (Anhambi Nutrição Animal, Itapejara d'Oeste, PR, Brazil), which was used as the control diet for 15 days prior to the trial for adaptation to the experimental conditions.

A total of 2.0 and $4.0 \mathrm{~g} \mathrm{~kg}^{-1}$ FOS from chicory (SigmaAldrich, Inc., St. Louis, MO, USA) were added to the commercial mix powder feed used in the adaptation period. A treatment without any supplementation ( $0 \mathrm{~g} \mathrm{~kg}^{-1}$ FOS), used as the control, was also evaluated. Both mixes were separately processed using the MX-40 laboratory extruder (Inbramaq Ind. Brasileira de Máquinas Ltda., Ribeirão Preto, SP, Brazil) and then compressed into $2.0 \mathrm{~mm}$ pellets. The extruded feeds were oven-dried, at $45^{\circ} \mathrm{C}$, for 24 hours, and the pellets were packed in plastic bags and stored under refrigeration until needed.

The trial was conducted in an indoor (12 hours light:12 hours dark photoperiod) water recirculation system composed of 12 rectangular tanks of $60 \mathrm{~L}$ each, with a biological filtration system, supplementary aeration, and temperature control. During all the experimental period, water quality parameters were measured daily with the HI98193 portable probe (Hanna Brasil, Barueri, SP, Brazil) to assess dissolved oxygen $\left(6.3 \pm 0.3 \mathrm{mg} \mathrm{L}^{-1}\right)$ and temperature $\left(26.9 \pm 2.8^{\circ} \mathrm{C}\right)$. 
The mPA-210 pH meter (MS Tecnopon, Piracicaba, SP, Brazil) was used to determine $\mathrm{pH}$, held at $6.1 \pm 0.1$.

At the beginning of the trial, juveniles were individually weighed (49.3 $\pm 4.3 \mathrm{~g}$ initial weight) and randomly assigned to $60 \mathrm{~L}$ tanks (10 fish per tank) in a completely randomized design with four replicates (fish groups) per treatment. Fish were fed with experimental diets until apparent satiety for 60 days, two times a day at 9:00 a.m. and 5:00 p.m. The tanks were cleaned every day after the last feeding.

At the end of the feeding trial, fish were fasted for 24 hours, anesthetized with $50 \mathrm{mg} \mathrm{L}^{-1}$ of an alcoholic solution of benzocaine, counted, weighed, and sampled for hematological and immunological analyses. Growth parameters were calculated according to Fracalossi et al. (2012).

Blood samples of four fish per tank (16 fish per treatment) were drawn from their caudal vessel using sterilized needles and syringes, and two aliquots were transferred to Eppendorf tubes (Eppendorf do Brasil, São Paulo, SP, Brazil) with and without heparin. Total red blood cells were counted with a Neubauer chamber using formaldehyde citrate buffer as a diluent; the hematocrit was determined in microhematocrit tubes after centrifugation for $5.0 \mathrm{~min}$, at $10,000 \mathrm{~g}$, and the hemoglobin content was obtained by cyanmethemoglobin on a spectrophotometer at $540 \mathrm{~nm}$. The hematimetric indices mean corpuscular volume $(\mathrm{MCV})$, mean corpuscular hemoglobin $(\mathrm{MCH})$, and mean corpuscular hemoglobin concentration (MCHC) were calculated. Blood smears from sampled fish were stained with the May-Grünwald-Giemsa stain for total leukocyte and thrombocyte count by the indirect method (Ishikawa et al., 2008).

The same fish sampled for the hematological analysis, were used for analyses of leukocy te respiratory burst, serum and mucus lysozyme concentration, and total serum protein concentration. The production of reactive oxygen species by leukocytes (respiratory burst) was determined by the nitroblue tetrazolium (NBT) colorimetric assay. An aliquot of $100 \mu \mathrm{L}$ of total heparinized blood was mixed with $100 \mu \mathrm{L}$ of $0.2 \%$ Nitrotetrazolium Blue Chloride solution (Sigma-Aldrich, St. Louis, MO, USA) and incubated for $30 \mathrm{~min}$ at $25^{\circ} \mathrm{C}$. After the incubation period, $50 \mu \mathrm{L}$ of this suspension were added to $1.0 \mathrm{~mL} \mathrm{~N}$, $\mathrm{N}$-dimethylformamide (Sigma-Aldrich, St. Louis, MO, USA) and centrifuged, at $755 \mathrm{~g}$, for $5.0 \mathrm{~min}$. Finally, the absorbance of the supernatant was measured at 540 $\mathrm{nm}$ using a spectrophotometer.

Serum lysozyme concentration was determined based on the lysis of Micrococcus lysodeikticus (SigmaAldrich, St. Louis, MO, USA), used as a standard. Before the fish serum analysis, a calibration curve was prepared from the L6876 standard lysozyme (SigmaAldrich, St. Louis, MO, USA) according to Abreu et al. (2009). Fish serum samples were obtained from blood stored in a microtube without anticoagulant and heated, at $56^{\circ} \mathrm{C}$, for $30 \mathrm{~min}$ to inactivate complement system proteins and certify that the lysis of M. lysodeikticus had occurred only by lysozyme action. Afterwards, $150 \mu \mathrm{L}$ fish serum and $150 \mu \mathrm{L}$ sodium phosphate buffer were added to a glass cuvette and incubated at $26^{\circ} \mathrm{C}$ for $2.0 \mathrm{~min}$ in a spectrophotometer, and $300 \mu \mathrm{L}$ M. lysodeikticus suspension $\left(0.2 \mathrm{mg} \mathrm{mL} \mathrm{mL}^{-1}\right.$ sodium phosphate buffer) were added to complete a $600 \mu \mathrm{L}$ final volume. The difference between the initial and final optical density was measured between 0.5 and $5.0 \mathrm{~min}$, at $450 \mathrm{~nm}$, also using a spectrophotometer. The equation of the lysozyme calibration curve was used to determine the serum lysozyme levels.

Fish mucus was collected to obtain lysozyme concentrations. Another three fish per tank (12 fish per treatment) were anesthetized with $50 \mathrm{mg} \mathrm{L}^{-1}$ of an alcoholic solution of benzocaine and immediately transferred to plastic bags containing $5.0 \mathrm{~mL}$ of 100 mol $\mathrm{NH}_{4} \mathrm{HCO}_{3}(\mathrm{pH} 7.8)$ for $60 \mathrm{~s}$. After this, the mucus extract was centrifugated, at $2,700 \mathrm{~g}$, for $15 \mathrm{~min}$ to remove fish scales and insoluble materials, frozen at $-20^{\circ} \mathrm{C}$, and lyophilized using the $\mathrm{L} 108$ equipment (Liobras, São Carlos, SP, Brazil) for further analysis of lysozyme concentrations, as previously described.

After totalblood centrifugation and serum collection, total serum protein concentrations were determined using the RHC-200 ATC portable refractometer (YHEquipment CO., Limited, Shenzhen, China), at $0.0 \sim 12.0 \mathrm{~g} \mathrm{dL}^{-1}$.

Data normality and homoscedasticity were previously analyzed using the Cramer Von Mises and Brown-Forsy the tests, respectively. When assumptions were met, the one-way analysis of variance was performed. If significant differences were registered, the differences between means were compared by Tukey's test, at $5 \%$ probability. 


\section{Results and Discussion}

Supplementing pacu juveniles with FOS for 60 days clearly improved fish growth (Table 1). Final weight, weight gain, specific growth rate, and feed conversion ratio were improved regardless of the inclusion level, although feed intake was not significantly affected by FOS levels.

The inclusion of $2.0 \mathrm{~g} \mathrm{~kg}^{-1}$ FOS increased growth and feed efficiency, which, however, did not show a significant improvement in fish fed with $4.0 \mathrm{~g} \mathrm{~kg}^{-1}$, as also reported for hybrid tilapia [Oreochromis niloticus (Linnaeus, 1758) $\times$ Oreochromis aureus (Steindachner, 1864] (Poolsawat et al., 2020). Similar responses were found for tambaqui juveniles fed with commercial diets supplemented with 1.0 to $5.0 \mathrm{~g} \mathrm{~kg}^{-1}$ FOS, with decreases in growth and feed efficiency after that (Paz et al., 2019). These authors suggest that levels of dietary FOS higher than $5.0 \mathrm{~g} \mathrm{~kg}^{-1}$ increase the expenditure of the basal metabolism, especially due to an improvement in the immune system, decreasing the energy available for fish growth. In fact, when compared with diets that were not supplemented, the dietary supplementation with FOS starting at $5.0 \mathrm{~g} \mathrm{~kg}^{-1}$ did not benefit the productive performance of several other fish species, such as rainbow trout (Ortiz et al., 2013), turbot [Scophthalmus maximus (Linnaeus, 1758)] (Guerreiro et al., 2016), and Japanese sea bass (Wang $\& \mathrm{Li}, 2020)$. Therefore, growth promotion due to FOS supply depends on complex and multifactorial factors, such as feeding levels and inter- and intraspecific features (Guerreiro et al., 2018a).
Fish hematology was also affected by dietary FOS supplementation (Table 2). The red blood cells of fish fed with $2.0 \mathrm{~g} \mathrm{~kg}^{-1}$ FOS significantly increased when compared with the other treatments. However, hematimetric indices such as $\mathrm{MCV}$ and $\mathrm{MHC}$ decreased in fish fed with $2.0 \mathrm{~g} \mathrm{~kg}^{-1} \mathrm{FOS}$. The obtained results were compatible with those previously reported for the species (Ranzani-Paiva et al., 1999; TavaresDias et al., 1999; Tavares-Dias, 2015), and no clinical signs of anemia were observed.

The dietary prebiotic stimulated the production of fish defense cells, and the number of both leukocytes and thrombocytes were higher at $2.0 \mathrm{~g} \mathrm{~kg}^{-1} \mathrm{FOS}$, followed by $4.0 \mathrm{~g} \mathrm{~kg}^{-1}$ and the control treatment (Table 2). These results indicate a better health status, since those cells participate in and are responsible for fish inflammatory and hemostatic responses against foreign substances such as pathogenic microorganisms (Rieger \& Barreda, 2011; Fink et al., 2015). Despite the increase in the number of defense cells, serum and mucus lysozyme concentration, leukocyte respiratory burst, and total serum protein were not affected (Table 3). Similar results were observed for rainbow trout fed with $5.0 \mathrm{~g} \mathrm{~kg}^{-1}$ dietary FOS for 70 days (Cid García et al., 2019).

The immunomodulation of prebiotics in fish has been previously reported, and the permanence and benefits of this modulation seem to be time dependent. In fact, FOS affect immune responses indirectly because the microbial fermentation of the prebiotic leads to the production of short-chain fatty acids, which improves gut probiotic microbiota, resulting in immune responses (Guerreiro et al., 2018a).

Table 1. Growth performance parameters of juvenile pacu (Piaractus mesopotamicus) fed with diets with increasing levels of fructooligosaccharides (FOS) for 60 days $^{(1)}$.

\begin{tabular}{|c|c|c|c|c|}
\hline \multirow[t]{2}{*}{ Parameters } & \multicolumn{3}{|c|}{ Dietary FOS supplementation levels $\left(\mathrm{g} \mathrm{kg}^{-1}\right)$} & \multirow{2}{*}{$\begin{array}{c}\text { One-way Anova }{ }^{(2)} \\
\text { (p-value) }\end{array}$} \\
\hline & 0.0 & 2.0 & 4.0 & \\
\hline Initial weight (g per fish) & $50.36 \pm 0.82$ & $49.12 \pm 2.77$ & $48.34 \pm 3.86$ & 0.686 \\
\hline Final weight (g per fish) & $94.72 \pm 7.06 b$ & $120.50 \pm 6.60 \mathrm{a}$ & $110.40 \pm 7.72 \mathrm{a}$ & 0.012 \\
\hline Weight gain (g per fish) & $44.35 \pm 7.98 \mathrm{~b}$ & $71.37 \pm 7.38 \mathrm{a}$ & $62.05 \pm 4.03 \mathrm{a}$ & 0.006 \\
\hline Daily feed intake (g per fish) & $2.09 \pm 0.08$ & $2.11 \pm 0.15$ & $2.01 \pm 0.14$ & 0.664 \\
\hline SGR (\% body weight per day) & $1.04 \pm 0.14 \mathrm{~b}$ & $1.49 \pm 0.13 \mathrm{a}$ & $1.37 \pm 0.03 \mathrm{a}$ & 0.008 \\
\hline Feed conversion ratio (FCR) & $2.88 \pm 0.40 \mathrm{a}$ & $1.78 \pm 0.06 \mathrm{~b}$ & $1.96 \pm 0.20 \mathrm{~b}$ & 0.005 \\
\hline
\end{tabular}

${ }^{(1)}$ Means followed by equal letters, in the rows, do not differ by Tukey's test, at 5\% probability. ${ }^{(2)}$ Analysis of variance. SGR, specific growth rate. 
In the present study, there was a trend of reduction in the beneficial effects of the defense blood cells (leukocytes and thrombocytes) in pacu fed with $4.0 \mathrm{~g}$ $\mathrm{kg}^{-1} \mathrm{FOS}$ for 60 days. Therefore, it is plausible to suppose that the absence of effects on the immunological parameters of pacu fed with FOS diets may be due to a long time of supplementation.

Moreover, the composition of the intestinal microbiota may change with time. In European sea bass, for instance, the supply of dietary FOS improved the richness and number of gut lactic acid bacteria after one to four weeks (Guerreiro et al., 2018b). However, in mirror carp [Cyprinus carpio (Linnaeus, 1758)] juveniles, diets supplemented with $\beta$-glucan caused positive effects on bacterial numbers and richness after only two weeks, disappearing after four weeks in the case of allochthonous microbiota (Kühlwein et al., 2013).

The time dependence of prebiotic modulation on the hematological and defense blood cells of pacu fed with mannan oligosaccharides was previously reported by Sado et al. (2014b). Additionally, Paz et al. (2019) highlighted an improvement in the growth and immunological parameters of tambaqui juveniles fed with 1.0 and $5.0 \mathrm{~g} \mathrm{~kg}^{-1}$ FOS diets from 15 to 45 days, but, when FOS levels were increased up to $20 \mathrm{~g} \mathrm{~kg}^{-}$ 1 , these parameters were similar to those of diets that were not supplemented. The use of FOS as a prebiotic for South American neotropical fish is still incipient and studies on time, rate, and feeding protocols, as well as on pacu physiology and immunology, are still scarce and needed for the safe use of FOS in aquaculture.

Table 2. Hematological parameters of juvenile pacu (Piaractus mesopotamicus) fed with diets with increasing levels of fructooligosaccharides (FOS) for 60 days ${ }^{(1)}$.

\begin{tabular}{|c|c|c|c|c|}
\hline \multirow[t]{2}{*}{ Parameters } & \multicolumn{3}{|c|}{ Dietary FOS supplementation levels $\left(\mathrm{g} \mathrm{kg}^{-1}\right)$} & \multirow{2}{*}{$\begin{array}{c}\text { One-way Anova }{ }^{(2)} \\
\text { (p-value) }\end{array}$} \\
\hline & 0.0 & 2.0 & 4.0 & \\
\hline $\operatorname{RBC}\left(10^{6}\right.$ cells $\left.\mu \mathrm{L}^{-1}\right)$ & $1.48 \pm 0.24 b$ & $2.33 \pm 0.29 \mathrm{a}$ & $1.58 \pm 0.14 b$ & $<0.0001$ \\
\hline Hematocrit (\%) & $33.1 \pm 4.7$ & $31.9 \pm 3.7$ & $32.9 \pm 3.0$ & 0.6439 \\
\hline Hemoglobin $\left(\mathrm{g} \mathrm{dL}^{-1}\right)$ & $5.24 \pm 0.69$ & $5.58 \pm 0.67$ & $5.30 \pm 0.56$ & 0.3992 \\
\hline $\mathrm{MCV}(\mathrm{fL})$ & $224.1 \pm 22.4 \mathrm{a}$ & $138.0 \pm 19.9 \mathrm{~b}$ & $202.3 \pm 21.7 \mathrm{a}$ & $<0.0001$ \\
\hline MHC $\left(\rho g\right.$ cell $\left.^{-1}\right)$ & $36.3 \pm 7.5 \mathrm{a}$ & $24.3 \pm 4.6 b$ & $33.8 \pm 5.6 \mathrm{a}$ & $<0.0001$ \\
\hline $\mathrm{MCHC}\left(\mathrm{g} \mathrm{dL}^{-1}\right)$ & $17.07 \pm 3.78$ & $17.77 \pm 3.30$ & $16.21 \pm 1.88$ & 0.4660 \\
\hline TLC $\left(10^{3}\right.$ cells $\left.\mu \mathrm{L}^{-1}\right)$ & $11.56 \pm 3.36 \mathrm{c}$ & $39.60 \pm 11.6 \mathrm{a}$ & $27.49 \pm 3.33 b$ & $<0.0001$ \\
\hline TC $\left(10^{3}\right.$ cells $\left.\mu \mathrm{L}^{-1}\right)$ & $6.97 \pm 2.17 \mathrm{c}$ & $20.46 \pm 3.59 \mathrm{a}$ & $14.42 \pm 3.64 \mathrm{~b}$ & $<0.0001$ \\
\hline
\end{tabular}

${ }^{(1)}$ Means followed by equal letters, in the rows, do not differ by Tukey's test, at $5 \%$ probability. ${ }^{(2)}$ Analysis of variance. RBC, red blood cells; MCV, mean corpuscular volume; MHC, mean corpuscular hemoglobin; MCHC, mean corpuscular hemoglobin concentration; TLC, total leukocyte count; and TC, thrombocyte count.

Table 3. Immunological parameters of juvenile pacu (Piaractus mesopotamicus) fed with diets with increasing levels of fructooligosaccharides (FOS) for 60 days ${ }^{(1)}$.

\begin{tabular}{lcccc}
\hline Parameters & \multicolumn{2}{c}{ Dietary FOS supplementation levels $\left(\mathrm{g} \mathrm{kg}^{-1}\right)$} & \multicolumn{2}{c}{$\begin{array}{c}\text { One-way Anova } \\
\text { (2) }\end{array}$} \\
\cline { 2 - 4 } (p-value)
\end{tabular}

${ }^{(1)}$ Means followed by equal letters, in the rows, do not differ by Tukey's test, at $5 \%$ probability. ${ }^{(2)}$ Analysis of variance. LRB, leukocyte respiratory burst; SLC, serum lysozyme concentration; MLC, mucus lysozyme concentration; and TSP, total serum protein concentration. 


\section{Conclusion}

The dietary supplementation with $2.0 \mathrm{~g} \mathrm{~kg}^{-1}$ fructooligosaccharides improves the growth parameters, modulates the immune system, and increases the circulating organic defense cells of juvenile pacu (Piaractus mesopotamicus).

\section{Acknowledgments}

To Conselho Nacional de Desenvolvimento Científico e Tecnológico (CNPq), for financial support (process number 426713/2016-8); to Coordenação de Aperfeiçoamento de Pessoal de Nível Superior (Capes), for financing, in part, this study (Finance Code 001) through the master's degree scholarship granted to the first author; and to Anhambi Alimentação Animal, for providing the basal powder diet.

\section{References}

ABREU, J.S.; MARZOCCHI-MACHADO, C.M.; URBACZEK, A.C.; FONSECA, L.M.; URBINATI, E.C. Leukocytes respiratory burst and lysozyme level in pacu (Piaractus mesopotamicus Holmberg, 1887). Brazilian Journal of Biology, v.69, p.1133-1139, 2009. DOI: https://doi.org/10.1590/S1519-69842009000500018.

AKRAMI, R.; IRI, Y.; ROSTAMI, H.K.; RAZEGHI MANSOUR, M. Effect of dietary supplementation of fructooligosaccharide (FOS) on growth performance, survival, lactobacillus bacterial population and hemato-immunological parameters of stellate sturgeon (Acipenser stellatus) juvenile. Fish \& Shellfish Immunology, v.35, p.1235-1239, 2013. DOI: https://doi.org/10.1016/j.fsi.2013.07.039.

BILLER-TAKAHASHI,J.D.;TAKAHASHI,L.S.;MARZOCCHIMACHADO, C.M.; ZANUZZO, F.S.; URBINATI, E.C. Disease resistance of pacu Piaractus mesopotamicus (Holmberg, 1887) fed with $\beta$-glucan. Brazilian Journal of Biology, v.74, p.698-703, 2014. DOI: https://doi.org/10.1590/bjb.2014.0083.

CID GARCÍA, R.A.; HERNÁNDEZ HERNÁNDEZ, L.H.; CARRILLO LONGORIA, J.A.; FERNÁNDEZ ARAIZA, M.A. Inclusion of yeast and/or fructooligosaccharides in diets with plant $\square$ origin protein concentrates for rainbow trout(Oncorhynchus mykiss) fingerlings. Journal of the World Aquaculture Society, v.51, p.970-981, 2019. DOI: https://doi.org/10.1111/jwas.12661.

FINK, I.R.; RIBEIRO, C.M.S.; FORLENZA, M.; TAVERNETHIELE, A.; ROMBOUT, J.H.W.M.; SAVELKOUL, H.F.J.; WIEGERTJES, G.F. Immune-relevant thrombocytes of common carp undergo parasite-induced nitric oxide-mediated apoptosis. Developmental \& Comparative Immunology, v.50, p.146-154, 2015. DOI: https://doi.org/10.1016/j.dci.2015.02.008.

FRACALOSSI, D.M.; RODRIGUES, A.P.O.; SILVA, T.S. de C. e; CYRINO, J.E.P. Técnicas experimentais em nutrição de peixes. In: FRACALOSSI, D.M.; CYRINO, J.E.P. (Ed.) Nutriaqua: nutrição e alimentação de espécies de interesse para a aquicultura brasileira. Florianópolis: Sociedade Brasileira de Aquicultura e Biologia Aquática, 2012. p.37-64.

GRISDALE-HELLAND, B.; HELLAND, S.J.; GATLIN III, D.M. The effects of dietary supplementation with mannanoligosaccharide, fructooligosaccharide or galactooligosaccharide on the growth and feed utilization of Atlantic salmon (Salmo salar). Aquaculture, v.283, p.163-167, 2008. DOI: https://doi.org/10.1016/j.aquaculture.2008.07.012.

GUERREIRO, I.; OLIVA $\square$ TELES, A.; ENES, P. Prebiotics as functional ingredients: focus on Mediterranean fish aquaculture. Reviews in Aquaculture, v.10, p.800-832, 2018a. DOI: https://doi.org/10.1111/raq.12201.

GUERREIRO, I.; SERRA, C.R.; OLIVA-TELES, A.; ENES, P. Short communication: gut microbiota of European sea bass (Dicentrarchus labrax) is modulated by shortchain fructooligosaccharides and xylooligosaccharides. Aquaculture International, v.26, p.279-288, 2018b. DOI: https://doi.org/10.1007/s10499-017-0220-4.

GUERREIRO, I.; ENES, P.; RODILES, A.; MERRIFIELD, D.; OLIVA-TELES, A. Effects of rearing temperature and dietary short-chain fructooligosaccharides supplementation on allochthonous gut microbiota, digestive enzymes activities and intestine health of turbot (Scophthalmus maximus L.) juveniles. Aquaculture Nutrition, v.22, p.631-642, 2016. DOI: https://doi.org/10.1111/anu.12277.

HAHOR, W.; THONGPRAJUKAEW, K.; SUANYUK, N. Effects of dietary supplementation of oligosaccharides on growth performance, gut health and immune response of hybrid catfish (Pangasianodon gigas $\times$ Pangasianodon hypophthalmus). Aquaculture, v.507, p.97-107, 2019. DOI: https://doi.org/10.1016/j. aquaculture.2019.04.010.

IBGE. Instituto Brasileiro de Geografia e Estatística. Produção da Pecuária Municipal 2019. Brasília, 2020. Available at: $<$ https://biblioteca.ibge.gov.br/visualizacao/periodicos/84/ ppm_2019_v47_br_informativo.pdf > Accessed on: Aug. 182021.

ISHIKAWA, N.M.; RANZANI-PAIVA, M.J.T.; LOMBARDI, J.V. Metodologia para quantificação de leucócitos totais em peixe, Oreochromis niloticus. Archives of Veterinary Science, v.13, p.54-63, 2008. DOI: https://doi.org/10.5380/avs.v13i1.11560.

KÜHLWEIN, H.; EMERY, M.J.; RAWLING, M.D.; HARPER, G.M.; MERRIFIELD, D.L.; DAVIES, S.J. Effects of a dietary $\beta$-(1,3)(1,6)-D-glucan supplementation on intestinal microbial communities and intestinal ultrastructure of mirror carp (Cyprinus carpio L.) Journal of Applied Microbiology, v.115, p.1091-1106, 2013. DOI: https://doi.org/10.1111/jam.12313.

LIU, W.; WANG, W.; RAN, C.; HE, S.; YANG, Y.; ZHOU, Z. Effects of dietary scFOS and lactobacilli on survival, growth, and disease resistance of hybrid tilapia. Aquaculture, v.470, p.50-55, 2017. DOI: https://doi.org/10.1016/j.aquaculture.2016.12.013.

NAWAZ, A.; BAKHSH JAVAID, A.; IRSHAD, S.; HOSEINIFAR, S.H.; XIONG, H. The functionality of prebiotics as immunostimulant: evidences from trials on terrestrial and aquatic animals. Fish \& Shellfish Immunology, v.76, p.272-278, 2018. DOI: https://doi.org/10.1016/j.fsi.2018.03.004. 
ORTIZ, L.T.; REBOLÉ, A.; VELASCO, S.; RODRÍGUEZ, M.L.; TREVIÑO, J.; TEJEDOR, J.L.; ALZUETA, C. Effects of inulin and fructooligosaccharides on growth performance, body chemical composition and intestinal microbiota of farmed rainbow trout (Oncorhynchus mykiss). Aquaculture Nutrition, v.19, p.475-482, 2013. DOI: https://doi.org/10.1111/j.13652095.2012.00981.x.

PAZ, A. de L.; SILVA, J.M. da; SILVA, K.M.M. da; VAL, A.L. Protective effects of the fructooligosaccharide on the growth performance, hematology, immunology indicators and survival of tambaqui (Colossoma macropomum, Characiformes: Serrasalmidae) infected by Aeromonas hydrophila. Aquaculture Reports, v.15, 100222, 2019. DOI: https://doi.org/10.1016/j. aqrep.2019.100222.

POOLSAWAT, L.; LI, X.; YANG, H.; YANG, P.; CHOWDHURY, M.A.K.; YUSUF, A.; LENG, X. The potentials of fructooligosaccharide on growth, feed utilization, immune and antioxidant parameters, microbial community and disease resistance of tilapia (Oreochromis niloticus $\times O$. aureus). Aquaculture Research, v.51, p.4430-4442, 2020. DOI: https://doi.org/10.1111/are.14786.

RANZANI-PAIVA, M.J.T.; SALLES, F.A.; EIRAS, J.C.; EIRAS, A.C. das; ISHIKAWA, C.M.; ALEXANDRINO, A.C. Análises hematológicas de curimbatá (Prochilodus scrofa), pacu (Piaractus mesopotamicus) e tambaqui (Colossoma macropomum) das estações de piscicultura do Instituto de Pesca, Estado de São Paulo. Boletim do Instituto de Pesca, v.25, p.77-83, 1998/1999.

RIEGER, A.M.; BARREDA, D.R. Antimicrobial mechanisms of fish leukocytes. Developmental \& Comparative Immunology, v.35, p.1238-1245, 2011. DOI: https://doi.org/10.1016/j. dci.2011.03.009.

SADO, R.Y.; BICUDO, A.J.A.; CYRINO, J.E.P. Growth and intestinal morphology of juvenile pacu Piaractus mesopotamicus (Holmberg 1887) fed dietary prebiotics (mannanoligosaccharides
- MOS). Anais da Academia Brasileira de Ciências, v.86, p.1517-1523, 2014a. DOI: https://doi.org/10.1590/00013765201420130088 .

SADO, R.Y.; BICUDO, A.J. de A.; CYRINO, J.E.P. Hematology of juvenile pacu, Piaractus mesopotamicus (Holmberg, 1887) fed graded levels of mannan oligosaccharides (MOS). Latin American Journal of Aquatic Research, v.42, p.30-39, 2014 b.

TAVARES-DIAS, M. Parâmetros sanguíneos de referência para espécie de peixes cultivados. In: TAVARES-DIAS, M.; MARIANO, W. dos S. (Org.). Aquicultura no Brasil: novas perspectivas. São Carlos: Pedro \& João, 2015. v.1, p.11-30.

TAVARES-DIAS, M.; TENANI, R.A.; GIOLI, L.D.; FAUSTINO, C.D. Características hematológicas de telósteos brasileiros: II. Parâmetros sangüíneos do Piaractus mesopotamicus Holmberg (Osteichthyes, Characidae) em policultivo intensivo. Revista Brasileira de Zoologia, v.16, p.423-431, 1999. DOI: https://doi.org/10.1590/S0101-81751999000200008.

VALLADÃO, G.M.R.; GALLANI, S.U.; PILARSKI, F. South American fish for continental aquaculture. Reviews in Aquaculture, v.10, p.351-369, 2018. DOI: https://doi.org/10.1111/ raq.12164.

WANG, C.-Y.; LI, Z.-B. Growth performance, digestive enzyme activity and immune response of Japanese sea bass, Lateolabrax japonicus fed with fructooligosaccharide. Aquaculture Nutrition, v.26, p.296-305, 2020. DOI: https://doi.org/10.1111/anu.12990.

ZHANG, C.-N.; LI, X.-F.; JIANG, G.-Z.; ZHANG, D.D.; TIAN, H.-Y.; LI, J.-Y.; LIU, W.-B. Effects of dietary fructooligosaccharide levels and feeding modes on growth, immune responses, antioxidant capability and disease resistance of blunt snout bream (Megalobrama amblycephala). Fish \& Shellfish Immunology, v.41, p.560-569, 2014. DOI: https://doi.org/10.1016/j.fsi.2014.10.005. 